\title{
Steps are Needed to Reduce Tensions in the Korean Triangle
}

\author{
Rene Wadlow
}

Harsh words and a feverish environment concerning the Korean Peninsula are such that there might be significant developments between the time this is written midSeptember and when Federalist Debate is published. However, we have to hope that reasonable efforts are made to reduce tensions and pave the way for a longer-range security system in Northeast Asia. We must do more than just watch events but try to see what type of opportunities exist for positive suggestions to governments or for "Track II" - non-official, NGO-led discussions .

Martin Wight, one of my professors of international relations, was concerned with analyzing recurrent relations among States ${ }^{1}$. He stressed the importance of what he called the "Strategic Triangle" as being of greater importance than bilateral relations. A strategic triangle requires looking at the range of diplomatic possibilities either to escalate the controversies or to aim to secure a political settlement among the three States.

The Korean Triangle is formed by North Korea (Democratic People's Republic of Korea -DPRK), the USA, and China. For the USA and China, the Korean issue is only one of its foreign policy concerns. There are ChinaUSA tensions on a number of other issues such as trade, monetary exchange rates, South China Sea islands, China's growing military capabilities, and more generally their place in the world. However, China is outside the current North Korea - US "sea of fire" verbal exchanges. Thus we can look to China for efforts to limit the escalation and to make proposals for a reduction of tensions. Both the Chinese President Xi Jinping and the Chinese Foreign Ministry have called for calm. "In the present situation, China believes all sides must remain calm and exercise restraint and not take actions which are mutually provocative, and must certainly not take actions which will worsen the situation." the Foreign Ministry has repeated. However, beyond repeating that a goal for China is a denuclearization of Korean Peninsula, there have been few proposals for tension reduction which can be carried out in the short term.

Denuclearization as well as some sort of confederal structure between the two Korean States (still called by the unlikely term of unification or reunification) are very longterm possibilities and do little to reduce the current build up of tensions.

For China, North Korea is a buffer against what it sees as an extension of US power, especially if there were an economic-socialpolitical disintegration on the pattern of East Germany which might lead to a refugee flow from North Korea to China. Thus for China, there is a need to maintain a stable status quo, and a lifting of U.N.-led sanctions which harm the North Korean economy without modifying its political policies. For China, trade with North Korea represents little in overall terms of trade; for North Korea trade 


\section{Comments}

with China, especially imports, represents a large percentage of its foreign trade.

Chinese influence on North Korean policy is limited. Chinese advice on economic reforms has been largely ignored, and what political advice is given is rarely made public. However, China serves as the only continuous avenue of diplomatic communications with North Korea and is more able than others to see if there are changes in attitudes or issues on which negotiations are a possibility.

There has been very little possibility for "Track II" - informal discussions among North Koreans, Americans, Chinese and South Koreans. Peace-related organizations have made public proposals for conflict reduction but, I fear, with little immediate impact. The Association of World Citizens had been pushing in 2013 - the anniversary of the 1953 armistice agreement - for a peace treaty since now all the States involved in the 1950-1953 war were members of the U.N. I had exchanges with Ban Ki-moon, the then Secretary-General and long-time Foreign Minister of the Republic of Korea on the subject. The idea of a peace treaty as a way to legitimize the two Korean States has recently been made again.

A more difficult to negotiate proposal has been made by several US peace groups including Peace Action which is an outgrowth of the earlier nuclear freeze movement of the $1980 s^{2}$. The new proposal is a "freeze for freeze" - a freeze on North Korea's nuclear and missile programs and a freeze on joint US-South Korean military exercises, perhaps with a progressive lessening of US troop presence.

World Citizens have also been advocating a speedy ratification process for the Nuclear Weapon Treaty which opened for signature on 20 September 2017 at the U.N. None of the nuclear-weapon States will sign so its ratification will not have a direct impact on the Korean situation, but rapid ratifications would indicate a broad willingness to eliminate nuclear weapons universally.

There have been various proposals made for a lifting of economic sanctions and a development of joint North-South Korea economic zones or other forms of economic cooperation. In the past economic cooperation has depended on the political atmosphere rather than economic cooperation creating a better political climate. This is likely to remain the case, but economic cooperation could significantly improve the level of life in North Korea which could have longer-range consequences.

There has been a good deal of saber-rattling on issues relating to the Korean Peninsula over the past few months. Since the sabers are sharp and increasingly nuclearized, we must see what can be done to reduce tensions and to develop a climate for negotiations in good faith.

\footnotetext{
${ }^{1}$ Martin Wight. System of States (Leicester: Leicester University Press, 1977). Martin Wight. Power Politics (New York: Viking Penguin, 1986) ${ }^{2}$ On the Nuclear Freeze movement in the USA see: Sonia Shah (Ed.) Between Fear and Hope: A Decade of Peace Activism (Baltimore, MD: Fortkamp Publishing, 1992)
} 